\title{
Illicit Drug Use by Adolescents: A Public Perception of Influencing Factors in Owerri, Nigeria
}

\section{Udochukwu Ugochukwu Ogu ( $\sim$ udo2ogu@gmail.com )}

University of Nigeria Teaching Hospital https://orcid.org/0000-0002-4643-5160

Nkoli Ezumah

University of Nigeria - Enugu Campus

Aloysius Odii

University of Nigeria

\section{Research}

Keywords: Public perception, illicit drug use, drug abuse, illicit drugs, drug control, adolescent, adolescent drug use, Nigeria

Posted Date: June 29th, 2020

DOI: https://doi.org/10.21203/rs.3.rs-38029/v1

License: (c) (i) This work is licensed under a Creative Commons Attribution 4.0 International License. Read Full License 


\section{Abstract}

Background: Illicit drug use among adolescents has become a social menace which cuts across all social strata. This study explored public perception of factors that influence illicit drug use among adolescents in Owerri, Nigeria.

Methods: A descriptive cross-sectional research design was used for the study. The study adopted a mixed method approach comprising quantitative and qualitative methods. The study was carried out in Owerri metropolis of Imo State, Nigeria. A total of 10 communities were selected randomly, they included four communities from the 16 communities that make up Owerri West, five communities from the 18 communities that make up Owerri North and one community from the five communities that make up Owerri Municipal. The research instruments used for data collection were questionnaires and in-depth interview guide.

Results: Our quantitative study found that $50.7 \%$ of the respondents, from across the three areas in Owerri metropolis, asserted that peer influence, emotional problems, relationship problems, wanting to feel 'high' are factors influencing adolescent consumption of illicit drugs whereas the qualitative study found family background, unique experience such as the death of a loved one, affliction or misfortune as factors influencing adolescents' illicit drug use. The quantitative results showed that persons with higher level of education are more likely than those with lower level of education to perceive a significant difference in drug use between in - school and out - of - school adolescents.

Conclusions: Peer pressure was identified as a major factor and it was also identified as rivaling the family in terms of influence.

\section{Background}

Recent trends indicate that the use and abuse of drugs have dramatically increased worldwide $(1-4)$. It has been estimated that between $3.6 \%$ and $6.9 \%$ of persons aged 15 to 64 years across the globe have used an illicit drug in the preceding year (5). World Health Organization (6) reported that 320, 000 young people between ages of 15 and 29 years die annually from alcohol and drug use, i.e., $9 \%$ of all the deaths in that age category and 15.3 million persons have drug use disorders. The global disease burden attributable to illicit drugs is estimated at 5.4\% (7).

Illicit drugs use (such as heroin, marijuana, etc.) particularly by adolescents, globally has been a public concern $(8,9)$. This is due to the potential short and long-term adverse effects or consequences associated with their use on the wellbeing of the users and the larger society (9). For instance, the use of marijuana by adolescents has been associated with an increased risk of a range of negative health outcomes, including future depression, anxiety disorders $(10,11)$, fatal automobile collisions $(10,12)$, accidental injuries, chronic bronchitis, and respiratory infections $(10,13)$. Frequent use of marijuana by adolescents, can have a detrimental impact on cognitive functioning and is likely to affect functional and structural development in areas of the brain involved in higher intellectual capabilities $(10,14,15)$. Adolescents that are involved in the use of illicit drugs, may display impaired judgment, contributing to risky behaviours such as engaging in unprotected sex (16).

Across the globe, there have been pointers to factors that influence adolescents' involvement in drug use. Some of the factors listed as reasons for adolescent involvement in illicit drug use are peer pressure, friends-do-it, sexual prowess, curiosity, boldness, enhanced spirit performance, social influence, psychological stress, pleasure, and inadequate knowledge of the harmful consequences etc. (17-20). Ndu, Ndu, Olarewaju and Somoye (21) added lack of selfconfidence, search for excitement, experimentation and conduct problems.

In Nigeria, majority of illicit drug users start at adolescence, as they tend to follow a particular pattern of involvement with drugs (22). Studies show that adolescents in Nigeria start using drugs as early as 10 years old (22-26). In a study 
by Adelekan and Ndom (25), the respondents reported using cannabis (marijuana) and cigarettes on a daily and weekly basis. A good number of adolescents ignorantly depend on one form of drug or the other for various daily activitiessocial, educational, political, moral etc. (27). These drugs include: Tobacco, Indian hemp, Cocaine, Morphine, Heroine, Ephedrine, Madras, Caffeine, Glue, Barbiturates, and Amphetamines (27).

There are several reports $(28,29)$ about the increase in drug use and its harmful effects. Youths from diverse sociocultural backgrounds have been known to use drugs (28), and this includes those from both rich and poor backgrounds. A study by Ilo (30) among secondary school students (aged 16-17 years) in Imo State, found that that the main drugs used by the students who took part in the study included analgesics, stimulants, anti-malaria, alcohol, worm expellant, nasal decongestants, sleeping pills, laxatives, and antibiotics and their main sources of drug information included print media, television, radio, and friends and peers. Another study (31) sought to determine the rate of substance abused, and adverse effects amongst senior secondary school students of Eziachi, Orlu, Imo state. The study found that majority of them abuse substances due to peer pressure, while for others it is due to academic adjustment, social and psychological factors. The most common reasons given for substance use was to have a feeling of belonging, followed by "to increase morale" and to have pleasure, to be awake, because it is cheap and is always available. The real number of drug users in Imo state, Nigeria is unknown. Other systems currently available to gauge drug use levels and trends, such as national household survey of drug use estimating the drug use in the total population have not been performed in Imo State till date (30).

Recently, researchers have started paying attention to the issue of illicit drug use in Nigeria $(17,18,26,32)$. However, most of these studies ignored public perception of illicit drug use among youths. Considering that the public has an important role to play in the attempt to reduce the rate of illicit drug use, how they perceive illicit drug use among youths must be ascertained. Moreover, how the public perceive an issue may reveal the level of attention it gets and the best strategies of addressing it. Because perception is shaped by things such as past experience, cultural expectations, motivations, moods, needs and attitudes $(33,34)$, ignoring it on issues that require modifying public policy or public behaviour, may result in the failure of technically good innovations. It is against this backdrop that this study focuses on exploring public perception of factors influencing illicit drug use among adolescents in Owerri metropolis.

\section{Theoretical framework}

Social Learning Theory (by Albert Bandura in 1977) and Expectancy theory (by Victor H. Vroom in 1964) were adopted as the framework for the study. Social Learning Theory holds that, behaviour is influenced by environmental factors, not just psychological or cognitive factors. Thus, Social Learning Theory assume that behavioural, psychological and environmental factors combined, influence the development of specific behaviours. In other words, what people are exposed to or observe could make all the difference in their lives. Expectancy theory, on the other hand, shows that individuals are most motivated if they believe they will receive a desired reward. What this means in line with this study is that individuals are likely to engage in drug use depending on what they perceive to be the outcome. Using these theories, this study ascertained the extent to which a person's behavioural intentions are affected by what he expects to experience and how much these expectations stand to cover the person's ability to see its damaging effects. The theory will also be relevant in exploring public perception towards these expectations and possible outcome.

\section{Study hypotheses}

1. 1. Males are more likely than females to perceive that adolescents would consume illicit drugs even if they knew the possible consequences.

2. 2. Persons with higher level of education are more likely than those with lower level of education to perceive a significant difference in drug use between in - school and out - of - school adolescents. 


\section{Methods}

\section{Study design and study area}

A descriptive cross-sectional research design was used for the study. The study adopted a mixed method approach comprising quantitative and qualitative methods. The area of study was Imo state, and there are 27 local government areas in Imo state. However, only three that make up Owerri metropolis were used for the study. The three local government areas that make up Owerri metropolis include Owerri West, Owerri North and Owerri Municipal. The choice of this study area arose from the fact that there are undocumented reports of illicit drug use and abuse among young people in the region.

\section{Study population and selection of study participants}

The study population consisted of members of the public aged 18 years and above, residing in Owerri metropolis at the time of the study. The projected (from the 2006 Nigerian Population Census) figures show that 403,425 people reside in Owerri metropolis. Specifically, Owerri North constitute 176,334; Owerri west constitute 101,754 while Owerri-municipal constituted $125,337$.

To ensure that Owerri metropolis' urban and rural communities and their respondents were truly represented in the population, a cluster sampling procedure was adopted. The justification for this is because Owerri metropolis has a considerable land mass and it will be difficult and expensive to cover such vast area. The 40 communities that comprise Owerri metropolis were represented with numbers and these numbers written on individual pieces of paper, folded and shuffled (selection by balloting). They were selected one after the other randomly until the desired figure was reached. The same procedure was repeated for the three local governments. A total of 10 communities were selected randomly in all: four communities from the 16 communities that make up Owerri West, five communities from the 18 communities that make up Owerri North and one community from the five communities that make up Owerri Municipal. Simple random sampling technique of balloting without replacement was used to determine which communities get picked from the LGAs. Using Yaro Yamane formula for determining finite population, using a significance level of 0.04 , the sample size for the study was 624 . In the four communities that were selected from Owerri West, 200 respondents were randomly selected. In the five communities that were selected from Owerri North, 220 respondents were randomly selected. In the one community that was selected from Owerri Municipal, 204 respondents were randomly selected. Information was collected from students living in off campus hostels, people in offices, markets and people found on the street all of whom meet the age category for the study.

\section{Instruments of data collection}

The research instruments used for data collection were questionnaires and in-depth interview guide. The questionnaire contained semi-structured questions. The questionnaire was developed based on the objective of the study. The questionnaire elicited information on the respondents' perception of factors influencing adolescents' involvement in illicit drug use, and consequences of these factors as well as strategies to curb illicit drug use among adolescents.

The interview guide contained structured questions on adolescent drug use, factors influencing their involvement as well strategies to curb them. A total of 16 respondents were purposively selected for in-depth interviews. Three respondents from a Psychiatric unit at Owerri (a representative of office of the director [RepOD], a doctor and a nurse), by virtue of their profession as medical and health personnel, the researchers believe that they would be well informed of the issue under investigation. A representative of the social welfare, at Owerri [RepSW], was also selected because it was believed that he would possess knowledge about deviant behaviours of young people in the metropolis. Also, twelve other respondents (four from each LGA) comprising of an elder statesman and woman, youth leaders and other 
influential community leaders were selected for the in-depth interview. The rationale for their selection was based on the assumption that they are knowledgeable about the subject matter and how it plays out in their respective communities.

\section{Data analysis}

The data from questionnaires were collated and coded manually and entries inputted into the computer. The data was analyzed with the Statistical Package for Social Sciences (SPSS version 21). The analysis employed descriptive statistics such as frequencies and percentages to present the characteristics of the research subjects. Chi-Square $\left(\chi^{2}\right)$ statistics was used in testing the hypothesis. In analyzing the qualitative data, the researcher began with careful transcription of the data. The transcripts derived from the in-depth interviews were read and coded with the Nvivo 11 software according to emerging themes. Thematic methods were used in the analysis of the qualitative data. The emerging themes were further grouped into major recurring themes and then analyzed accordingly. Salient illustrative quotes were then pulled out to complement and elucidate the quantitative data in reporting the results.

\section{Results}

Out of the total of 624 questionnaires that were distributed in the course of the study, 535 questionnaires were properly filled and returned - showing a response rate of $85.7 \%$. Specifically, 209 questionnaires were returned from respondents in Owerri North, 221 and 105 questionnaires in Owerri West and Municipal respectively.

\section{Socio-demographic Data Of The Respondents}


Table 1

highlights the distribution of respondents according to their sex, age, educational attainment, marital status and occupation.

\begin{tabular}{|c|c|c|c|}
\hline \multicolumn{4}{|l|}{ Socio-demographics } \\
\hline Sex & No of Respondents & Percentage $(q$ & \\
\hline Male & 255 & 47.7 & \\
\hline Female & 280 & 52.3 & \\
\hline Total & 535 & 100 & \\
\hline Age of respondents & Male (\%) & Female (\%) & Total (\%) \\
\hline $18-27$ years & $110(43.1)$ & 93(33.2) & 203(37.9) \\
\hline 28-37 years & $33(12.9)$ & 101(36.1) & $134(25.0)$ \\
\hline $38-47$ years & $60(23.6)$ & $42(15.0)$ & 102(19.2) \\
\hline $48-57$ years & 48(18.8) & 41(14.6) & $89(16.6)$ \\
\hline 58 years and above & $4(1.6)$ & $3(1.1)$ & $7(1.3)$ \\
\hline Total & 255(100) & 280(100) & $535(100)$ \\
\hline Educational attainment & Male (\%) & Female (\%) & \\
\hline No formal education & $12(4.7)$ & $44(15.7)$ & $56(10.5)$ \\
\hline Primary school & $22(8.6)$ & $47(16.8)$ & $69(12.9)$ \\
\hline Secondary school & $29(11.4)$ & 92 (32.9) & $121(22.6)$ \\
\hline N.C.E* & $42(16.5)$ & $18(6.4)$ & $60(11.2)$ \\
\hline OND/HND** & $50(19.6)$ & 38 (13.5) & $88(16.5)$ \\
\hline B.Sc./B.Tech. & $80(31.4)$ & $40(14.3)$ & $120(22.4)$ \\
\hline Other (specify) & $20(7.8)$ & $1(0.4)$ & $21(3.9)$ \\
\hline Total & $255(100)$ & $280(100)$ & $535(100)$ \\
\hline Marital status & Male (\%) & Female (\%) & \\
\hline Married & $64(25.1)$ & $127(45.4)$ & 191(35.7) \\
\hline Widowed & $0(0)$ & $23(8.2)$ & $23(4.3)$ \\
\hline Divorced & $9(3.5)$ & 10(3.6) & $19(3.6)$ \\
\hline Separated & 19(7.5) & $32(11.4)$ & $51(9.5)$ \\
\hline Single & $163(63.9)$ & $88(31.4)$ & 251(46.9) \\
\hline Total & $255(100)$ & $280(100)$ & $535(100)$ \\
\hline Occupation & Male (\%) & Female (\%) & \\
\hline Unemployed & $23(9.0)$ & $42(15.0)$ & $65(12.1)$ \\
\hline
\end{tabular}




\begin{tabular}{|c|c|c|c|}
\hline \multicolumn{4}{|c|}{ Socio-demographics } \\
\hline Trading & $77(30.2)$ & $122(43.6)$ & 199(37.2) \\
\hline Business & $145(56.9)$ & 88(31.4) & $233(43.6)$ \\
\hline Civil service & $4(1.5)$ & $26(9.3)$ & $30(5.6)$ \\
\hline Other (specify ) & $6(2.4)$ & $2(0.7)$ & $8(1.5)$ \\
\hline Total & $255(100)$ & $280(100)$ & $535(100)$ \\
\hline
\end{tabular}

\section{Factors Influencing Adolescents' Involvement In Illicit Drug Use}

The information in Table 2 shows that across all three LGAs, $50.7 \%$ of the respondents, in a multiple item response choice asserted that peer influence, emotional problems, relationship problems, wanting to feeling 'high' and 'other' identified reasons (such as, early childhood abuse, to fight depression, media projects drugs as okay, easy access to drugs and isolation) are factors influencing adolescent consumption of illicit drugs. Furthermore, $14.4 \%$ of the respondents felt that peer influence and emotional problems only, are factors that predispose adolescents to engaging in the consumption of illicit drugs. Also, while $8.0 \%$ of the respondents averred that emotional problems and wanting to feel 'high' are factors that predispose adolescents to engaging in the consumption of illicit drugs, $9.9 \%$ felt that relationship problems and wanting to feel 'high' are factors that predispose adolescents to engaging in the consumption of illicit drugs. Additionally, $8.2 \%$ of the respondents were of the opinion that adolescents in the area engage in the consumption of illicit drugs because they want to perform better in competitions (e.g., debate, sports, etc) and because of emotional problems. However, $8.8 \%$ of the respondents felt that other reasons other than those mentioned in the questionnaire were responsible for adolescents' consumption of illicit drugs in the study area. This result is an indication that majority of the respondents hold the view that peer influence, emotional problems, relationship problems, wanting to feeling 'high' and 'other' identified reasons are factors that predispose adolescents to engaging in the consumption of illicit drugs.

Table 2

Distribution of respondents on the reasons why adolescents consume the types of drugs they consume

\begin{tabular}{|lllll|}
\hline $\begin{array}{l}\text { Why do adolescents consume the types of drugs they do? } \\
\text { (multiple choice response) }\end{array}$ & $\begin{array}{l}\text { North } \\
(\%)\end{array}$ & West (\%) & $\begin{array}{l}\text { Municipal } \\
(\%)\end{array}$ & Total (\%) \\
\hline $\begin{array}{l}\text { Peer influence, Emotional problems, Relationship problems, To } \\
\text { feel 'high', Other }\end{array}$ & $99(47.4)$ & $107(48.4)$ & $65(61.9)$ & $271(50.7)$ \\
\hline Peer influence, Emotional problems & $27(12.9)$ & $38(17.2)$ & $12(11.4)$ & $77(14.4)$ \\
\hline Emotional problems, To feel 'high' & $18(8.6)$ & $22(10.0)$ & $3(2.9)$ & $43(8.0)$ \\
\hline Relationship problems, To feel 'high' & $23(11.0)$ & $22(10.0)$ & $8(7.6)$ & $53(9.9)$ \\
\hline $\begin{array}{l}\text { To perform better in competitions (e.g., debate, sports, etc), } \\
\text { Emotional problems }\end{array}$ & $12(5.7)$ & $18(8.1)$ & $14(13.3)$ & $44(8.2)$ \\
\hline Other (specify) & $30(14.4)$ & $14(6.3)$ & $3(2.9)$ & $47(8.8)$ \\
\hline Total & $209(100)$ & $221(100)$ & $105(100)$ & $535(100)$ \\
\hline
\end{tabular}


For the qualitative findings, respondents were asked to give reasons why they think adolescents consume illicit drugs. Reacting to this, respondents mentioned such factors as peer pressure, family background, emotional problems, major life events or unique experience (death of a loved one, affliction or misfortune), youthful exuberance, the need to feel 'high', mass media, personality factors, among others. Respondents were also asked to discuss the ways in which these factors impact on adolescents' choice of illicit drug use and behaviour. One of the respondents who described how emotional problems impact adolescents' choice of illicit drug use and behaviour had this to say:

"We are all emotional creatures and feel the impact of happenings around us and to us either directly or indirectly on a daily basis. For example, someone may feel that the economic realities are so harsh and thus insolvent and may experience depression. Depending on his/her ability to cope with the situation, such a person may take to illicit drugs as a temporary measure to forget about his/her environment" (RepOD).

Another respondent who spoke extensively on how major life events or unique experience (death of a loved one, affliction or misfortune) can influence adolescents' illicit drug use opined that:

"We live in a world where events and certain situations are bound to take place. Sometimes, the death of a loved one can create a vacuum in one's heart that only drugs can fill, even if its short lived. Also, some experience can cause a dramatic change in a persons' life to an extent that taking to drugs become the only escape route. For instance, a rape or incest victim may constantly take to drugs whenever she thinks of the horrific experience she had. This would temporarily put her mind away from the situation. Such event like this can have a long term impact on an adolescent's drug use choice and practice" (Nurse).

\section{If adolescents would consume illicit drugs if they knew the possible consequences}

Respondents views were sought on whether or not adolescents would consume illicit drugs (e.g., cocaine, weed, etc) if they knew the possible consequences. According to the data in Table 3, over half (58.3\%) of the entire respondents disagreed that adolescents would consume illicit drugs (e.g., cocaine, weed, etc) if they knew the possible consequences; $34.6 \%$ agreed, while $7.1 \%$ indicated that they did not know the likely outcome. Specifically, more females than males in Owerri west (82.6\% females compared to $63.4 \%$ males) and Owerri north $(72.0 \%$ females compared to $62.7 \%$ males) disagreed that adolescents would consume illicit drugs if they knew the possible consequences. Also, while $36.3 \%$ of the male and $28.0 \%$ of the female respondents agreed that adolescents would consume illicit drugs if they knew the possible consequences, only $1.0 \%$ of the male respondents did not know whether adolescents would consume illicit drugs if they knew the consequences. Similarly, while $35.7 \%$ of the male and $17.4 \%$ of the female respondents agreed that adolescents would consume illicit drugs if they knew the possible consequences, only $0.9 \%$ of the male respondents did not know whether adolescents would consume illicit drugs if they knew the consequences. Nevertheless, the highest proportions of both male (62.1\%) and female (48.9\%) respondents in Owerri metropolis agreed that adolescents would consume illicit drugs if they knew the possible consequences. While $34.5 \%$ of male and $34.0 \%$ of female respondents did not know whether adolescents would continue to consume illicit drugs even if they knew the consequences, $3.4 \%$ of male and $17.0 \%$ of female respondents disagreed with the view. 
Table 3

Distribution of respondents by sex and whether adolescents would consume illicit drugs (e.g., cocaine, weed, etc.) if they knew its possible consequences

\begin{tabular}{|llllllll|}
\hline $\begin{array}{l}\text { Would adolescents still } \\
\text { consume illicit drugs if they } \\
\text { knew their consequences? }\end{array}$ & North (\%) & Male (\%) & $\begin{array}{l}\text { Female } \\
\text { (\%) }\end{array}$ & Male (\%) & $\begin{array}{l}\text { Female } \\
\text { (\%) }\end{array}$ & $\begin{array}{l}\text { Male } \\
\text { (\%) }\end{array}$ & $\begin{array}{l}\text { Female } \\
(\%)\end{array}$ \\
\hline Yes & $37(36.3)$ & $30(28.0)$ & $40(35.7)$ & $19(17.4)$ & $36(62.1)$ & $23(48.9)$ & $185(34.6)$ \\
\hline No & $64(62.7)$ & $77(72.0)$ & $71(63.4)$ & $90(82.6)$ & $2(3.4)$ & $8(17.0)$ & $312(58.3)$ \\
\hline Don't know & $1(1.0)$ & - & $1(0.9)$ & - & $20(34.5)$ & $16(34.1)$ & $38(7.1)$ \\
\hline Total & $102(100)$ & $107(100)$ & $112(100)$ & $109(100)$ & $58(100)$ & $47(100)$ & $535(100)$ \\
\hline
\end{tabular}

The information in Table 4 shows a sex disaggregated distribution of respondents on reasons adolescents would consume illicit drugs (e.g., cocaine, weed, etc) if they knew their possible consequences. The result shows that a high proportions of both male $(29.0 \%$ ) and female respondents (33.3\%) from Owerri North stated that because habitual compulsive behaviours are difficult to change, adolescents would continue to consume illicit drugs even if they knew the possible consequences. Also $35.5 \%$ of male respondents stated that the belief that these consequences are over exaggerated encouraged adolescents to continue to consume illicit drugs. More of female respondents $(19.4 \%)$ than their male counterparts $(12.9 \%)$ argued that peer group influence is a motivator for continuous illicit drugs among adolescents. In Owerri West, $70.5 \%$ of the male respondents argued that social comparison, the belief that the consequences of illicit drug use are over exaggerated and the fact that habitual compulsive behaviours are difficult to change explains why adolescents would not stop using illicit drug use. Meanwhile, the highest proportion of the female respondents (48.0\%) from Owerri West was of the view that the fact that habitual compulsive behaviours are difficult to change explains why adolescents would not stop using illicit drug use. Also, $32.0 \%$ of the female respondents in this area also stated that social comparison and the belief that the consequences of illicit drug use are over exaggerated explains why adolescents would not stop using illicit drug. In the Municipal area, majority of both male $(67.7 \%)$ and female $(57.1 \%)$ respondents expressed the view that the fact that habitual compulsive behaviours are difficult to change explains why adolescents would not stop using illicit drug use.,. However, more females (17.9\%) than males (9.7\%) expressed the view that the belief that the consequences of illicit drug use are over exaggerated explains why adolescents would not stop using illicit drug use despite having knowledge of its negative effects.

In sum, $42.2 \%$ of the entire study respondents believed that because it is difficult to change habitual compulsive behaviours, adolescents would continue to use illicit drugs even if they knew about the possible consequences; meanwhile $12.4 \%, 10.3 \%, 18.4 \%, 14.6 \%$ and $2.2 \%$ thought that peer group influence, social comparison, belief that the consequences of illicit drugs are over exaggerated, the belief that present feeling can't be compared to any latter consequences and youthful exuberance respectively, account for why adolescents would continue to take to illicit drugs even if they knew the possible consequences. Overall, the result implies that the perception that habitual behaviours are difficult to change and thus encouraging adolescents to continue to take to illicit drugs was expressed by majority of the study respondents. 
Table 4

Distribution of respondents by sex and their reasons why adolescents would consume illicit drugs (e.g., cocaine, weed, etc) if they knew its possible consequences

\begin{tabular}{|c|c|c|c|c|c|c|c|}
\hline \multirow{2}{*}{$\begin{array}{l}\text { Reasons adolescents would } \\
\text { consume illicit drugs despite } \\
\text { knowledge of their effect }\end{array}$} & \multicolumn{2}{|l|}{ North (\%) } & \multicolumn{2}{|l|}{ West (\%) } & \multicolumn{2}{|c|}{ Municipal (\%) } & \multirow[t]{2}{*}{ Total (\%) } \\
\hline & $\begin{array}{l}\text { Male } \\
(\%)\end{array}$ & $\begin{array}{l}\text { Female } \\
(\%)\end{array}$ & $\begin{array}{l}\text { Male } \\
(\%)\end{array}$ & $\begin{array}{l}\text { Female } \\
(\%)\end{array}$ & $\begin{array}{l}\text { Male } \\
(\%)\end{array}$ & $\begin{array}{l}\text { Female } \\
(\%)\end{array}$ & \\
\hline Peer group influence & $4(12.9)$ & $7(19.4)$ & $4(11.8)$ & $2(8.0)$ & $2(6.5)$ & $4(14.3)$ & $23(12.4)$ \\
\hline Social comparisons & $2(6.5)$ & $3(8.3)$ & $8(23.5)$ & $4(16.0)$ & $2(6.5)$ & - & 19(10.3) \\
\hline $\begin{array}{l}\text { Belief that consequences are } \\
\text { over exaggerated }\end{array}$ & $11(35.5)$ & $7(19.4)$ & $4(11.8)$ & $4(16.0)$ & $3(9.7)$ & $5(17.9)$ & $34(18.4)$ \\
\hline $\begin{array}{l}\text { The belief that present feeling } \\
\text { can't be compared to any latter } \\
\text { consequences }\end{array}$ & $5(16.1)$ & $7(19.4)$ & $8(23.5)$ & $3(12.0)$ & $3(9.7)$ & $1(3.6)$ & $27(14.6)$ \\
\hline $\begin{array}{l}\text { Habitual compulsive } \\
\text { behaviours are difficult to } \\
\text { change }\end{array}$ & $9(29.0)$ & 12(33.3) & $8(23.5)$ & $12(48.0)$ & $21(67.7)$ & $16(57.1)$ & $78(42.2)$ \\
\hline Youthful exuberance & - & - & $2(5.9)$ & - & & $2(7.1)$ & $4(2.2)$ \\
\hline Total & $31(100)$ & $36(100)$ & $34(100)$ & $25(100)$ & $31(100)$ & $28(100)$ & $185(100)$ \\
\hline
\end{tabular}

In order to complement the quantitative data, we asked the IDI respondents the following: To what extent are adolescents likely to use drugs like marijuana, cocaine, tobacco and alcohol if they knew the possible consequences? Here, the majority of the respondents averred that the knowledge of the consequences of drug intake cannot necessarily decrease its usage. To them, the instant gratification and the euphoria that come with drug use may encourage adolescents to rationalize illicit drug use. One of the respondents puts it this way:

"Because adolescents perceive issues relating to the implications of illicit drugs on human lives as an abstract subject, they tend to justify the existence of drugs. Some of the adolescents go as far as arguing that illicit drug use is as old as man and because a pocket of people die due to drug use, does not mean that it will kill everyone. One of the younger folks I counseled at a time, told me that drug kills people who are not smart at taking it. The implication is this: it is either the usage increases or stays the same way" (Nurse).

Other respondents who perceived that the knowledge of the consequences of illicit drugs can influence adolescents to decrease their drug intake expressed the view that adolescents may find it very difficult to actually stop; however, they can decide to stop or reduce the intake if they are faced with pernicious situations. Bolstering this position, one of the respondents averred that: "the crisis that comes with addiction and the whole withdrawal symptoms thing can make the knowledge of the consequences of illicit drugs meaningless" (Youth leader, male).

Respondents were asked to state whether there is a difference in drug use between adolescents who are in school and those who are not. In line with this, Table 5 shows that $51.4 \%$ stated that there is a difference in drug use between inschool and out-of-school adolescents. On the contrary, $37.4 \%$ of the respondents said there is no difference. However, $11.2 \%$ of the respondents did not know whether a difference exists. This result reflects the fact that majority of the respondents find a difference in drug use between adolescents who are in school and those who are not. Furthermore, we asked respondents who thought there is a difference between adolescents who are in school and those who are not to state these differences, they believed that in-school adolescents are less likely to engage in drug use than out-ofschool adolescents because they are more knowledgeable about the consequences and more exposed than out-ofschool adolescents. 
Table 5

Distribution of Respondents on whether there is a difference in drug use between adolescents who are in school and those who are not

\begin{tabular}{|lllll|}
\hline Difference? & North (\%) & West (\%) & Municipal (\%) & Total (\%) \\
\hline Yes & $100(47.8)$ & $144(65.2)$ & $31(29.5)$ & $275(51.4)$ \\
\hline No & $77(36.8)$ & $60(27.1)$ & $63(60.0)$ & $200(37.4)$ \\
\hline Don't know & $32(15.4)$ & $17(7.7)$ & $11(10.5)$ & $60(11.2)$ \\
\hline Total & $209(100)$ & $221(100)$ & $105(100)$ & $535(100)$ \\
\hline
\end{tabular}

\section{Hypotheses}

\section{Hypothesis 1}

Males are more likely than females to perceive that adolescents would consume illicit drugs if they knew the possible consequences.

$\mathrm{H}_{1}$

Males are more likely than females to perceive that adolescents would consume illicit drugs if they knew the possible consequences.

$\mathrm{H}_{0}$

Males are less likely than females to perceive that adolescents would consume illicit drugs if they knew the possible consequences.

This hypothesis was tested using analyzed data in Tables 1 and 3. While data in Table 1 contains respondents' information on sex, Table 3 contained information on the perception of respondents on whether adolescents would consume illicit drugs if they knew the possible consequences. Furthermore, respondents' information in Table 3 was recoded and categorized into two independent categories; with respondents who said 'don't know' being excluded from the categories and thus the analysis. In order to test this hypothesis, a chi-square $\left(X^{2}\right)$ test of independence and the statistical package (SPSS 21.0) were employed. However, a cross tabulation of the independent variable (respondents' sex) and the dependent variable (respondents' perception on whether adolescents would consume illicit drugs if they knew the possible consequences) were computed and presented in Table 12 below:

Table 12

Respondents' sex and perception on whether adolescents would consume illicit drugs if they knew the possible consequences

\begin{tabular}{|llll|}
\hline \multirow{2}{*}{$\begin{array}{l}\text { Respondents' } \\
\text { sex }\end{array}$} & \multicolumn{2}{l}{ Adolescents would consume illicit drugs if they knew the possible consequences } & Total \\
\cline { 2 - 3 } & Yes $(\%)$ & No $(\%)$ & $244(49.1)$ \\
\hline Male & $112(60.5)$ & $132(42.3)$ & $253(50.9)$ \\
\hline Female & $73(39.5)$ & $180(57.7)$ & $497(100)$ \\
\hline Total & $185(100)$ & $312(100)$ & \\
\hline$X^{2}=15.5, \mathrm{df}=1, \mathrm{~N}=497, \mathrm{p}<.001$ & & \\
\hline
\end{tabular}


From Table 12 above, it could be observed that of all the respondents who said that adolescents would consume illicit drugs even if they knew the possible consequences, majority were males (60.5\%) and the remaining $39.5 \%$ were females. On the other hand, more than half of the respondents who disagreed with this statement were females while the remaining $42.3 \%$ were males. This output suggests that there were more female than male respondents who did not think that adolescents would consume illicit drugs if they knew the possible consequences.

A further observation of the chi-square output shows a statistically significant difference in the proportion of male and female respondents regarding their perception of whether adolescents would still consume illicit drugs even if they knew the consequences $\left(X^{2}=15.5 ; \mathrm{df}=1, \mathrm{~N}=497, \mathrm{P}<.001\right)$. In other words, the $X^{2}$ value of 15.5 indicates a remarkable difference between the observed proportional differences and what is expected by chance occurrence. In order to ensure that no assumptions were violated, appropriate steps were taken, and it was established that the calculated $X^{2}$ value at 15.5 is greater than the tabulated value $X^{2}$ value at 10.828 . As a result, the substantive hypothesis that: "Male respondents are more likely than female respondents to perceive that adolescents would consume illicit drugs if they knew the possible consequences." is upheld.

\section{Hypothesis 2}

Persons with higher level of education are more likely than those with lower level of education to perceive a significant difference in drug use between in - school and out - of - school adolescents.

$\mathrm{H}_{1}$

Persons with higher level of education are more likely than those with lower level of education to perceive a significant difference in drug use between in - school and out - of - school adolescents.

\section{$\mathrm{H}_{0}$}

Persons with higher level of education are less likely than those with lower level of education to perceive a significant difference in drug use between in - school and out - of - school adolescents.

The hypothesis was tested using analyzed data in Tables 1 and 5. While the data in Table 5 contains respondents' information on whether there is a difference in drug use between adolescents who are in school and those who are not (e.g., dropouts), the data in Table 1 containing information on respondents educational levels (amongst others) were recategorized with respondents with no formal education, primary school and secondary school classified as belonging to a lower educational level (246 in all) and respondents in the other categories as those with a higher level of education (289 in all). Here, respondents' information in Table 5 were re-coded and categorized into two independent categories; with respondents who said 'don't know' being excluded from the analysis. Here, only 475 respondents' information were used for testing the hypothesis. In order to test this hypothesis, a chi-square $\left(X^{2}\right)$ test of independence and the statistical package (SPSS 21.0) were employed. This response is reflected in Table 13. 
Table 13

Respondents' educational levels and their perception on whether there is a difference in drug use between adolescents who are in school and those who are not

\begin{tabular}{|c|c|c|c|}
\hline \multirow{2}{*}{$\begin{array}{l}\text { Respondents' } \\
\text { Educational } \\
\text { Levels }\end{array}$} & \multicolumn{2}{|c|}{$\begin{array}{l}\text { perception of drug use between adolescents who are in school and those who } \\
\text { are not }\end{array}$} & \multirow[t]{2}{*}{ Total } \\
\hline & Yes (\%) & No (\%) & \\
\hline High & 175(71.4) & 100(43.5) & $275(57.9)$ \\
\hline Low & $70(28.6)$ & $130(56.5)$ & $200(42.1)$ \\
\hline Total & $245(100)$ & $230(100)$ & $475(100)$ \\
\hline \multicolumn{3}{|c|}{$X^{2}=36.9, d f=1, N=497, p<.001$} & \\
\hline
\end{tabular}

From Table 13, it could be observed that of all the study respondents who perceived a difference between adolescents who are in school and those who are not as regards their drug use, a greater majority $(71.4 \%)$ were in the category of those with higher educational level, while the remaining $28.6 \%$ were in the category of those with lower educational level. On the other hand, majority of the respondents (56.5\%) who perceived that there is no difference between adolescents who are in school and those who are not as regards their drug use were in the category of those with higher educational level, while the remaining $43.5 \%$ were in the category of those with lower educational level. Overall, more respondents with higher level of education than those with a lower level of education perceived a difference between adolescents who are in school and those who are not as regards their drug use. A further observation of the chi-square output shows a statistically significant difference in the proportion of respondents with higher level of education and those with a lower level perceived a difference between adolescents who are in school and those who are not as regards their drug use $\left(X^{2}=36.9 ; \mathrm{df}=1, \mathrm{~N}=497, \mathrm{P}<.001\right)$. In other words, the $X^{2}$ value of 15.5 indicates a remarkable difference between the observed proportional differences and what is expected by chance occurrence. In order to ensure that no assumptions were violated, appropriate steps were taken, and it was established that the calculated $X^{2}$ value at 36.9 is greater than the tabulated value $X^{2}$ value at 10.828 . As a result, the substantive hypothesis that: "Respondents with higher level of education are more likely than those with lower level of education to perceive a significant difference in drug use between in - school and out - of - school adolescents." is upheld.

\section{Discussion}

The study examined the perception of the public on factors influencing illicit drug use among adolescents. According to the findings of the study, $50.7 \%$ of the respondents, from across the three areas in Owerri metropolis asserted that peer influence, emotional problems, relationship problems, media, youthful exuberance, wanting to feel 'high' and 'other' identified reasons are factors that motivate adolescents to consume illicit drugs. This finding is consistent with that of Nwoke, Ogba \& Ugwu (35) and Ukwayi, Eja \& Uwanede (36) who found that peer pressure, emotional problems and wanting to feel high are some of the motivating factors for undergraduates' use of illicit drugs in Nigerian universities. In the current study, peer influence was a factor that was frequently mentioned and this underscores the influence of such a group on deviant behaviours. One of the reasons why peer influence is so important, particularly during the stage of adolescence is perhaps due to its crucial role as an agent of socialization. Although, the peer group is second only to the parents in socializing the child, the peer group equals the family in terms of influence over adolescents (37). This could be because "adults and parents would not discuss certain sensitive issues, which the adolescents are curious about; adolescents are left to deal with these issues on their own. The 'most experienced' in the peer group usually takes the lead, gives advices and plays a parental role to other adolescents who are in desperate need of acceptance". 
Second, the study attempted to identify the categories of adolescents (i.e. in - school or out - of - school) involved in the use of drugs in Owerri metropolis. Result revealed that there is no difference in the proportion of respondents (whether in - school or out - of - school) as to the categories of adolescents who engage more in drug use in the study area. Similarly, the hypotheses tested in this regard shows that there is no significant difference in perceived drug use between in - school and out - of - school adolescents $\left(X^{2}=0.42 ; \mathrm{df}=1, \mathrm{~N}=535, \mathrm{P}<.05\right)$. This goes to show that it does not matter the categories of adolescents (whether in or out-of-school, in rural or urban area, male or female, etc.) when it comes to illicit drugs use, both categories are same. This finding is in congruence with that of Omigbodun \& Babalola (38) which found that for both in-and out-of-school adolescents, the socially acceptable drugs like alcohol and cigarettes are commonly used.

The study derived its theoretical framework from the following theories: expectancy theory (39) and social learning theory (40). At this point, the current study has helped to revalidate the expectancy theory in that it shows how individuals are most likely to engage in drug use depending on what they perceive to be the outcome. For instance, in this study, we found that the public perceives that adolescents are most likely to consume drugs because of reasons such as wanting to feel 'high'. This appears like an outcome with 'great' benefits, and explains why adolescents take drugs even when they know the consequences. Using this theory, this study has demonstrated the extent to which a person's behavioural intentions can be affected by what he/she expects to experience and how much these expectations mar the person's ability to see its damaging effects. Most importantly, this theory can help in understanding young people's psychology towards illicit drug consumption and can also contribute to the development of effective strategies and interventions.

Finally, the study has helped to validate social learning theory and expectancy theory. According to the theories, behaviour is influenced by environmental factors and promise of desirable outcomes, not just psychological or cognitive factors. In the current study, we have found that peer influence, emotional problems, relationship problems, media, youthful exuberance, wanting to feel 'high' and other reasons are perceived factors that motivate adolescents to consume illicit drugs. All of these factors represent either or all of the concepts developed in the social learning theory and expectancy theory. For instance, while peer pressure could be representative of the environmental factors, emotional problems or youthful exuberance, and wanting to feel 'high' could be representative of the behavioural factors, psychological factors and how/what they expect to feel, respectively. This theories can also serve as resource tools in the development of intervention strategies in tackling drug problems especially among adolescents.

\section{Study Limitations}

The study only focused on the public's perception of factors that influence the drug use of adolescents. It however, did not discuss the public's perception on the consequences or the strategies to curbing this menace.

\section{Conclusion}

Peer influence, emotional problems, relationship problems, the influence of media (especially the social media), youthful exuberance, wanting to feeling 'high' among several other identified reasons are factors that motivate adolescents to consume illicit drugs. More particularly, peer pressure was identified by majority of the respondents as a major factor and it was also identified as rivaling the family in terms of influence. The reason given for this development is that the stage of adolescence is filled with inquisitiveness and the zeal to explore and experiment on new things, so, in the case where the family is not around or available to provide guidance and answers to these questions, the peer group plays the parenting role in the affair of adolescents who desperately are in need of acceptance. The study equally concludes that although out-of-school adolescents engage more in the use of illicit

Page $14 / 18$ 
drugs than adolescent in school, rural, urban, broken homes and normal families, there is no statistically significant difference in the proportion of respondents as to their perception on who (whether in - school or out - of - school) engages more in drug use in the study area. This suggests that education or some schooling experience may not in actuality, be a determinant of adolescents' illicit drug choice or behaviour.

\section{Abbreviations}

\section{LGA}

Local Government Area

N.C.E.

National Certificate Examination

O.N.D.

Ordinary National Diploma

H.N.D.

Higher National Diploma

RepOD

A representative of the office of the director

RepSW

A representative of the Social Welfare

\section{Declarations}

\section{Ethic Approval and consent to participate}

The study was approved by the ethics committee of the department of Sociology/Anthropology, University of Nigeria, Nsukka. Each participant was given a consent form to sign showing their consent to participate in the study.

\section{Consent for publication}

Not applicable.

\section{Availability of data and materials}

The datasets used and/or analyzed during the current study are available from the corresponding author on reasonable request.

\section{Competing interest}

The authors declare that there are no competing interests.

\section{Funding}

This study was personally funded by the lead author. There were no other sources of funding.

\section{Authors' contribution}

OUU conceived the topic and prepared the first draft. EN guided the creation of the topic and also reviewed and made strategic inputs to the paper, section by section until the final draft. AO reviewed and made strategic inputs to the paper. All authors read and approved the final manuscript 
Acknowledgement

Not applicable.

Authors' information

OUU has a M.Sc. in Medical Sociology from University of Nigeria, Nsukka. EN is a retired Professor from the department of Sociology/Anthropology, University of Nigeria, Nsukka. AO is a lecturer with the department of Sociology/Anthropology, University of Nigeria, Nsukka.

\section{References}

1. Deressa W, Azazh A. Substance use and its predictors among undergraduate medical students of Addis Ababa University in Ethiopia. BMC Public Health. 2011;11(1):660.

2. Gebreslassie M, Feleke A, Melese T. Psychoactive substances use and associated factors among Axum University students, Axum Town, North Ethiopia. BMC Public Health. 2013;13(1):693.

3. FMCPsych AOA, FMCPsych SS. ALCOHOL AND PSYCHOACTIVE SUBSTANCE USE AMONG. MEDICAL STUDENTS OF THE UNIVERSITY OF ILORIN, NIGERIA.

4. Reddy P, Resnicow K, Omardien R, Kambaran N. Prevalence and correlates of substance use among high school students in South Africa and the United States. Am J Public Health. 2007;97(10):1859-64.

5. United Nations. World Drug Report 2013 UNITED NATIONS OFFICE ON DRUGS AND CRIME Vienna [Internet]. 2013 [cited 2020 May 26]. Available from: www.unodc.org.

6. World Health Organization. Global Status Report on Alcohol and Health 2011 [Internet]. WHO. 2012 [cited 2018 May 26]. Available from: https://www.who.int/substance_abuse/publications/alcohol_2011/en/.

7. World Health Organization. Atlas on substance use (2010): resources for the prevention and treatment of substance use disorders [Internet]. 2010 [cited 2019 May 26]. Available from: https://www.who.int/publicationsdetail/9789241500616.

8. Kalsi H. Substance abuse amongst high school and college students. 2015.

9. Tshitangano TG, Tosin $\mathrm{OH}$. Substance use amongst secondary school students in a rural setting in South Africa: Prevalence and possible contributing factors. African J Prim Heal care Fam Med. 2016;8(2):1-6.

10. Resko SM. Public perceptions and attitudes toward adolescent marijuana use: Results of a statewide survey. Sage Open. 2014;4(1):2158244013518055.

11. Rey JM, Martin A, Krabman P. Is the party over? Cannabis and juvenile psychiatric disorder: the past 10 years. J Am Acad Child Adolesc Psychiatry. 2004;43(10):1194-205.

12. Asbridge M, Hayden JA, Cartwright JL. Acute cannabis consumption and motor vehicle collision risk: systematic review of observational studies and meta-analysis. Bmj. 2012;344:e536.

13. Hall W, Degenhardt L. Adverse health effects of non-medical cannabis use. Lancet. 2009;374(9698):1383-91.

14. Medina KL, Nagel BJ, Tapert SF. Abnormal cerebellar morphometry in abstinent adolescent marijuana users. Psychiatry Res Neuroimaging. 2010;182(2):152-9.

15. Schweinsburg AD, Brown SA, Tapert SF. The influence of marijuana use on neurocognitive functioning in adolescents. Curr Drug Abuse Rev. 2008;1(1):99-111.

16. Gruber AJ, Pope HG Jr. Marijuana use among adolescents. Pediatr Clin North Am. 2002;49(2):389-413.

17. Oluremi Fareo D. DRUG ABUSE AMONG NIGERIAN. ADOLESCENTS STRATEGIES FOR COUNSELLING. J Int Soc Res. 2012;5(20). 
18. Adegoke AA, Olasupo MO, Ayeni OB. Prevalence and pattern of male adolescents' substance abuse in Ibadan metropolis. Int J Soc Sci Educ. 2014;4(4):890-7.

19. Alhyas L, Al Ozaibi N, Elarabi H, El-Kashef A, Wanigaratne S, Almarzouqi A, et al. Adolescents' perception of substance use and factors influencing its use: a qualitative study in Abu Dhabi. Jrsm Open.

2015;6(2):2054270414567167.

20. Osman T, Victor C, Abdulmoneim A, Mohammed H, Abdalla F, Ahmed A, et al. Epidemiology of substance use among university students in Sudan. J Addict. 2016;2016.

21. Ndu FO, Ndu LO, Olarewaju AO, Somoye F. Basic Science: An Integrated Science Course for Junior Secondary School 1. Ikeja: Longman Nigeria Plc; 2009.

22. Ndom RJE, Igbokwe DO, Ekeruo N. Students' Opinion on Substance Use, Violent Behavior and Possible Intervention Strategies in a Nigerian Public University. Eur Sci Journa. 2012;8(19):191-211.

23. Fatoye FO, Morakinyo O. Substance use among secondary school students in rural and urban communities in South Western Nigeria. East Afr Med J. 2002;79(6):299-305.

24. Shehu AU, Idris SH. Marijuana smoking among secondary school students in Zaria, Nigeria: Factors responsible and effects on academic performance. Ann Afr Med. 2008;7(4).

25. Adelekan ML, Ndom RJ. Trends in prevalence and pattern of substance use among secondary school pupils in Ilorin, Nigeria. West Afr J Med. 1997;16(3):157-64.

26. Chikere EIC, Mayowa MO. Prevalence and perceived health effect of alcohol use among male undergraduate students in Owerri, South-East Nigeria: a descriptive cross-sectional study. BMC Public Health. 2011;11(1):118.

27. Mamman H, Othman AT, Lian LH. Adolescent's and drugs abuse in Nigeria. J Biol Agric Healthc. 2014;4(1):5-9.

28. Abasiubong F, Udobang JA, Idung AU, Udoh SB, Jombo HE. A comparative study of pattern of substance use in two Nigerian cities located in the Southern and Northern Nigeria. African Res Rev. 2014;8(2):52-67.

29. United Nations Office on Drugs and Crime. WORLD DRUG REPORT 2010 [Internet]. 2010 [cited 2020 May 26 ]. Available from: https://www.unodc.org/documents/wdr/WDR_2010/World_Drug_Report_2010_lo-res.pdf.

30. Ilo Cl. Drug Use and Sources of Drug Information Among Secondary School Students in Imo State, Nigeria. Eur J Educ Sci. 2017;4(1):76-85.

31. PREVALENCE OF SUBSTANCE ABUSE AMONG STUDENTS OF EZIACH SENIOR SECONDARY SCHOOL ORLU LOCAL GOVERNMENT AREA

IMO STATE

Ibebuike JE, Nwokike IG, Iquiro AA, Ibebuike KE, Nwinyinya OP, Oti I. PREVALENCE OF SUBSTANCE ABUSE AMONG STUDENTS OF EZIACH SENIOR SECONDARY SCHOOL ORLU LOCAL GOVERNMENT AREA, IMO STATE. 2017.

32. Adebiyi AO, Faseru B, Sangowawa AO, Owoaje ET. Tobacco use amongst out of school adolescents in a Local Government Area in Nigeria. Subst Abuse Treat Prev Policy. 2010;5(1):24.

33. Severin WJ, Tankard JW. Communication theories: Origins, methods, and uses in the mass media. Longman New York; 1997.

34. Sadaf A. Public perception of media role. Int J Humanit Soc Sci. 2011;1(5):228-36.

35. Nwoke MB, Ogba KTU, Ugwu NC. Family and peer influence on drug use among Nigerian youth. Int J Res Arts Soc Sci. 2012;4.

36. Ukwayi JK, Eja OF, Unwanede CC. Peer Pressure and Tobacco Smoking among Undergraduate Students of the University of Calabar, Cross River State. High Educ Stud. 2012;2(3):92-101.

37. Seun AV. The Effects of Drug Abuse among University Undergraduates in Nigeria (The Case of Federal University, Oye-Ekiti) [Internet]. Federal University, Oye-Ekiti; 2013. Available from:

Page $17 / 18$ 
https://www.academia.edu/17085799/The_effects_of_Drug_Abuse_among_University_undergraduates_in_Nigeria.

38. Omigbodun OO, Babalola O. Psychosocial dynamics of psychoactive substance misuse among Nigerian adolescents. 2004.

39. Vroom VH. Work and motivation. 1964.

40. Bandura A. Self-efficacy: toward a unifying theory of behavioral change. Psychol Rev. 1977;84(2):191. 